\title{
Aloe Vera Gel Coating Retains Persimmon Fruit (Diospyros kaki) Quality during Storage at Room Temperature
}

\author{
Abdul Jalal, Abdur Rab* and Naveed Ahmad
}

Department of Horticulture, Faculty of Crop Production Sciences, University of Agriculture, Peshawar, Pakistan.

\begin{abstract}
Storage durations and Aloe vera gel concentrations significantly decreased the loss of persimmon fruit quality during storage at room temperature. Storage at room temperature $\left(26 \pm 2^{\circ} \mathrm{C}\right)$ resulted in significant decline in fruit firmness, percent acidity, and ascorbic acid content with a concomitant increase in total soluble solids (TSS), organoleptic quality (Taste) score and decay incidence. Coating of persimmon fruits with $30 \%$ Aloe vera gel retarded the storage related changes and retained high fruit firmness, acidity and ascorbic acid as well as lower total soluble solids and decay incidence than control fruits. In control fruits (0 days storage + Distilled water treatment), the fruit firmness $\left(3.33 \mathrm{~kg} \mathrm{~cm}^{-2}\right)$, acidity $(0.29 \%)$, and ascorbic acid content (46.25 $\mathrm{mg} / 100 \mathrm{~g}$ ) decreased to $0.06 \%, 16.47 \mathrm{mg} / 100 \mathrm{~g}$ and $0.56 \mathrm{~kg} \mathrm{~cm}^{-2}$, respectively, and the TSS (12.45\%) and decay incidence (12.55\%) increased to 37.56 and $100 \%$ respectively during 35 days storage at room temperature. By contrast, fruit treated with $30 \%$ Aloe vera gel retained high fruit firmness $\left(2.46 \mathrm{~kg} \mathrm{~cm}^{-2}\right)$, acidity $(0.19 \%)$, ascorbic acid content $(29.76 \mathrm{mg} / 100 \mathrm{~g})$ as well as lower TSS (20.2\%) and decay incidence (43.85\%) after 35 days storage at room temperature.

Received | March 24, 2019; Accepted | August 23, 2020; Published | October 17, 2020

*Correspondence $\mid$ Abdur Rab, Department of Horticulture, Faculty of Crop Production Sciences, University of Agriculture, Peshawar, Pakistan; Email: abdurrab@aup.edu.pk

Citation | Jalal, A., A. Rab and N. Ahmad. 2020. Aloe vera gel coating retains persimmon fruit (Diospyros kaki) quality during storage at room temperature. Sarhad Journal of Agriculture, 36(4): 1094-1102.

DOI | http://dx.doi.org/10.17582/journal.sja/2020/36.4.1094.1102

Keywords | Aloe vera, Ascorbic acid, Persimmon, Quality, TSS
\end{abstract}

\section{Introduction}

$\mathrm{P}$ ersimmon (Diospyros kaki), belonging to family Ebenaceae, is native to oriental Asia (Baltacioglu and Artik, 2013). The persimmon fruit is a good source of ascorbic acids, sugars, carotenoids, organic acids, vitamins, minerals, phenolic compounds and dietary fiber (Del-Bubba et al., 2009; Veberic et al., 2010). Being rich in ascorbic acid and phenolic compounds, the persimmon fruit may protect against oxidative stress (Scalbert and Williamson, 2000; Suzuki et al., 2005). The Persimmon fruit rapidly deteriorates during storage mainly due moisture loss and pathological disorders (Gorinstein et al., 2001). Pre and postharvest infections causing decay and moisture loss are the major causes of quality deterioration during storage (Terry and Joyce, 2004; Misir et al., 2014). Thus, delaying softening and disease control are the primary techniques to extend the storage life of persimmon fruit (Khademi, 2012).

Attempts have been made to increase the storage life of persimmon fruit by the application of chemicals (Zheng et al., 2006; Bagheri et al., 2015). However, the use of chemicals to increase the postharvest life of fruits has limited scope due to potential risks to human health (Asghari et al., 2013). Recently edible coatings have developed for preserving the horticultural commodities and improve the appearance of the fruit (Mandal et al., 2009). Edible 
coatings prevent moisture loss and reduce the rate of respiration during storage, thus, delays senescence (Serrano et al., 2006). Some edible coatings are added with anti-microbial compounds to prevent disease incidence and retain visual quality (Cha and Chinnan, 2004).

Aloe vera gel has long been used for medicinal purposes (Valverde et al., 2005). Aloe vera gel has two major components; the liquid yellow latex and clear gel extract from the parenchyma tissue of the leaves (Ni et al., 2004). Aloe vera gel is mainly used in industries for making cosmetics and can be used for healing of wounds, burns and scars (Serrano et al., 2006). Due to its waxy nature and anti-microbial activities, Aloe vera gel can also be used as bio preservative to extend the storage life of horticultural commodities (Martinez-Romero et al., 2006). Aloe vera gel, as a coating material, suppressed respiration, decreases fruit softening, reduce moisture loss, delays senescence, reduced microorganism proliferation and delays oxidative browning in sweet cherries, table grapes, nectarines and papaya (Ahmad et al., 2009; Marpudi et al., 2013). Keeping in view the potential benefits of Aloe vera Gel, as bio-preservative and edible coating material, the current research was conducted to evaluate the influence of different concentrations of Aloe vera $\mathrm{Gel}$ on the ripening and quality losses of persimmon fruit during storage at room temperature.

\section{Materials and Methods}

The influence of different concentrations of Aloe vera gel, as a bio preservative, on the storage life and quality of persimmon fruit was investigated by treating persimmon fruits with $0,10,20,30$ and $40 \%$ Alove vera gel and storage for $0,7,14,21,28$ and 35 days at room temperature. Persimmon fruits (Var. Seedless Persimmon; PCNA type: Pollination constant non astringent) were harvested from Horticulture Farm of the University of Agriculture, Peshawar, during the month of October, 2014 at Physiological (pinkish stage of) maturity. The fruits were carefully shifted to the laboratory in wooden boxes. Physically sound and healthy fruits were separated and washed with running tap water followed by rinsing with distilled water. The surface moisture was removed from the fruits with a gentle blower. Total number of treatments were 60 and the number of fruits per treatment was 8 having the size of $129 \pm 3 \mathrm{~cm}^{3}$.
Aloe vera gel preparation

Fully matured leaves of Aloe vera plants were harvested early in the morning and shifted to the postharvest Laboratory. The Aloe vera leaves were positioned in upright orientation, in an iron stand for 30 minutes to remove all the yellow latex. The vertical corners of leaves were removed and then cut into slices along with the green rind tissue. The transparent gel was carefully separated from the rind tissue, blended in a blender and filtered through a soft netted cloth to remove any particle of the rind and fiber tissue. The Aloe vera juice was collected in a beaker wrapped with light protecting paper (Adetunji et al., 2012). The Aloe vera juice was stored in dark jar and kept at refrigerated temperature $\left(4^{\circ} \mathrm{C}\right)$ to prevent spoilage (Mohebbi et al., 2011). This gel was then heated in oven for 45 minutes at $70{ }^{\circ} \mathrm{C}$ and then cooled to the ambient temperature adding 2 g. $\mathrm{L}^{-1}$ of ascorbic acid and warmed to $23^{\circ} \mathrm{C}$ for 15 minutes adding $4.5 \mathrm{~g}$. $\mathrm{L}^{-1}$ of citric acid for maintaining its $\mathrm{pH}$ at 4 (Marpudi et al., 2013). Different concentrations of Aloe vera gel were prepared by adding gel to distilled water.

\section{Treatment of fruits}

The persimmon fruit were carefully dipped in different concentrations (0,10,20,30 and 40\%) of Aloe vera gel for 5 minutes and allowed to stay on clean paper sheet for 15 minutes. The fruits were then stored for 0,7 , $14,21,28$ and 35 days at room temperature $(26 \pm 2$ $\left.{ }^{\circ} \mathrm{C}\right)$. The fruits were evaluated for different quality parameters at the end of each storage interval.

\section{Evaluation of quality parameters}

Fruit firmness was measured with handhold penetrometer (Effegi Fruit Firmness Tester- FT 327). A small portion fruit skin, at the equatorial region of the fruit, was peeled and the penetrometer probe was gently inserted into the peeled surface to the desired depth (as per manufacturer's protocol) and the fruit firmness was recorded.

Decay incidence was recorded by storing a separate lot of 50 fruit from each treatment and replication. The number of fruits with disease or decay symptoms were calculated at each storage interval and converted to percent decay incidence using the following formula.

Decay incidence $(\%)=\frac{\text { Number of fruits with decay incidence at storage interval }}{\text { Number of stored fruits }} \times 100$

The organoleptic quality evaluation was carried out by panel of 5 judges and scored at 1-9 points' hedonic 
scale (Raza et al., 2013). The fruit samples, treated with various Aloe gel concentrations were evaluated for as organoleptic quality attributes (color and taste) at each storage interval. The score allocated was averaged to represent the organoleptic quality of the persimmon fruit.

The Total Soluble Solids (TSS) was estimated with a handhold refractometer (Crisosto-MT-032) at each storage interval. For this purpose, the fruit juice was extracted from the fruits and a few drops were added to the prism of refractometer and slid was placed properly and TSS content was recorded. The prism was washed with distilled water between successive readings.

The titratable acidity of the fruits was determined at each storage interval by titration of the fruit juice sample against $0.1 \mathrm{~N} \mathrm{NaOH}$ solution (AOAC, 1990). For this purpose, $10 \mathrm{ml}$ sample of fruit juice was taken in a graduated cylinder and the volume was made to $100 \mathrm{ml}$ with distillated water. Titration of $10 \mathrm{ml}$ from the $100 \mathrm{ml}$ sample was done against $0.1 \mathrm{~N} \mathrm{NaOH}$ solution using liquid phenopthaline as an indicator till the persistence of light pink color. Three readings were taken for each treatment and then the means of these reading were calculated. The calculation of percent acidity was done by the given formula.

$$
\operatorname{Acidity}(\%)=\frac{T \times 0.0067 \times 100}{L \times M}
$$

\section{Where;}

$\mathrm{T}=\mathrm{NaOH}$ used (ml); $\mathrm{L}=$ Sample taken in wt. for dilution; $\mathrm{M}=$ Diluted sample taken for titration in $\mathrm{ml}$.

The ascorbic acid of the fruits was estimated for all the treatment at each storage interval by titrating the fruit juice sample against dye standard solution AOAC (1990). The dye solution was prepared by taking $50 \mathrm{mg}$ 2, 6 Dichlorophenol Indophenol dye and $42 \mathrm{mg}$ Sodium Bicarbonate $\left(\mathrm{NaHCO}_{2}\right)$ in a beaker containing distilled water. It was heated for 30 minutes at a magnetic stirrer. When the chemicals were fully dissolved, the volume was made to $250 \mathrm{ml}$ in a volumetric flask.

The dye solution was standardized $50 \mathrm{mg}$ of ascorbic acid was dissolved in $50 \mathrm{ml}$ of $0.4 \%$ oxalic acid and then $2 \mathrm{ml}$ of from this solution was titrated against dye in a conical flask till the appearance of pink color.
The reading of dye was noted on the burette and dye factor was calculated using the given formula:

$$
\text { Dye facros }(F)=\frac{\text { Ascorbic acid solution }(\mathrm{ml})}{\text { Volumeof Dye solution used }}
$$

For the calculation of ascorbic acid dilution of $10 \mathrm{ml}$ of fruit juice was done in $0.4 \%$ oxalic acid prepared solution making the volume of $100 \mathrm{ml}$. Titration of $10 \mathrm{ml}$ from the $100 \mathrm{ml}$ sample solution was done against dye using liquid phenopthaline as an indicator till the persistence of light pink color. The formula used for calculation of ascorbic acid is.

$$
\text { Ascorbic Acid }=\frac{F \times T X 100 \times 100}{D \times S}
$$

\section{Where;}

$\mathrm{F}=\mathrm{Dye}$ factor; $\mathrm{T}=\mathrm{ml}$ of dye sol. Used from burette; $\mathrm{D}=$ Diluted sample $(\mathrm{ml})$ taken for titration; $\mathrm{S}=$ fruit juice $(\mathrm{g})$ taken for dilution.

\section{Statistical analysis}

The experiment was laid out in Completely Randomized Design (CRD) with two factors, repeated three times. Factor A was Aloe vera gel concentrations $(0,10,20,30$ and $40 \%)$ and factor B was storage duration ( $0,7,14,21,28$ and 35 days). The data was analyzed using SAS software and the treatment means were separated by LSD test as described by Steel and Torrie (1997).

\section{Results and Discussion}

\section{Fruit firmness $\left(\mathrm{kgcm}^{-2}\right)$}

The fruit firmness decreased significantly $(\mathrm{P} \leq 0.05)$ with increasing storage duration and was retained by increasing the concentrations of Aloe vera gel. The fruit firmness of fresh (0 days of storage) fruit (3.33$3.40 \mathrm{kgcm}^{-2}$ ) decreased with incremental increase in storage duration. The lowest fruit firmness $(0.56$ $\mathrm{kgcm}^{-2}$ ) after 35 days storage at room temperature was in control fruit. The fruit firmness at 35 days storage duration was 1.3 and $1.43 \mathrm{kgcm}^{-2}$ for fruit coated with 10 and 20\% Aloe vera gel, that increased to the maximum $\left(2.68 \mathrm{kgcm}^{-2}\right)$ in fruits treated with $40 \%$ gel, that was at par with fruit firmness $(2.46$ $\mathrm{kgcm}^{-2}$ ) with application of $30 \%$ gel. Furthermore, no significant changes was found in 30 and $40 \%$ gel treatment (Figure 1). 


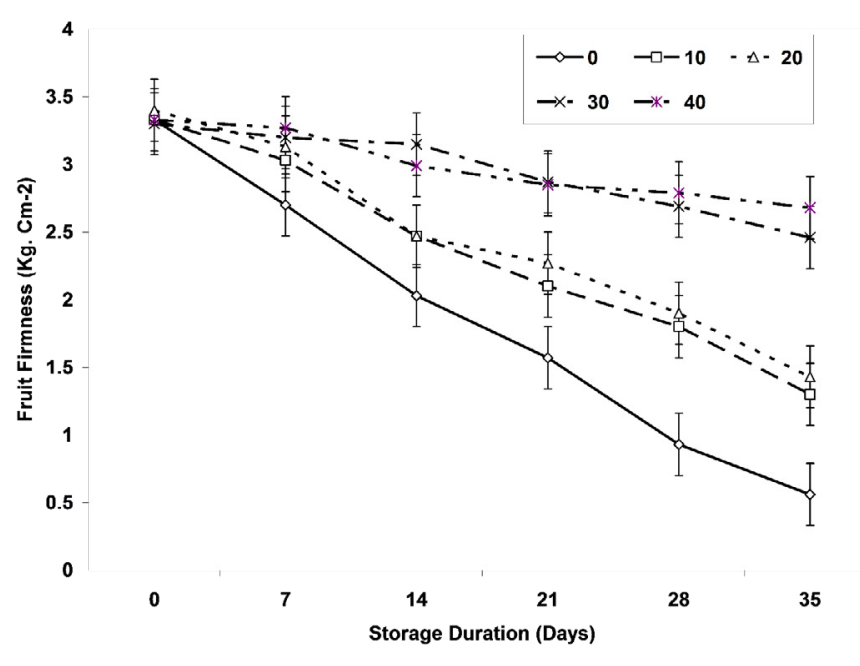

Figure 1: The effect of storage duration and Aloe vera gel concentrations on the firmness of persimmon fruit. The error bars represent LSD at $P \geq 0.05$.

\section{Decay incidence (\%)}

The interaction of storage duration and Aloe vera gel concentrations affected the fruit decay incidence significantly $(P \leq 0.05)$. After 7 days storage, there was no decay incidence in fruits coated with Aloe vera gel, but $12.5 \%$ decay incidence was observed in control fruits ( $0 \%$ gel concentration) that increased to the maximum of $100 \%$ after 35 days storage. The application of Aloe vera gel delayed the appearance of decay symptoms and decreased the decay incidence. The decay incidence was observed after 14, 21 and 28 days storage in fruits treated with 10, 20 and 30\% Aloe vera gel coating. However, fruit coated $40 \%$ Aloe vera gel showed decay symptoms after 21 days storage. After 35 days storage at room temperature the maximum decay incidence (100\%) was in persimmon fruit treated with 0 and $10 \%$ Aloe vera gel, that decreased to $42.25 \%$ with 30\% gel application but increased to 66.66 with application of $40 \%$ Aloe vera gel (Figure 2).

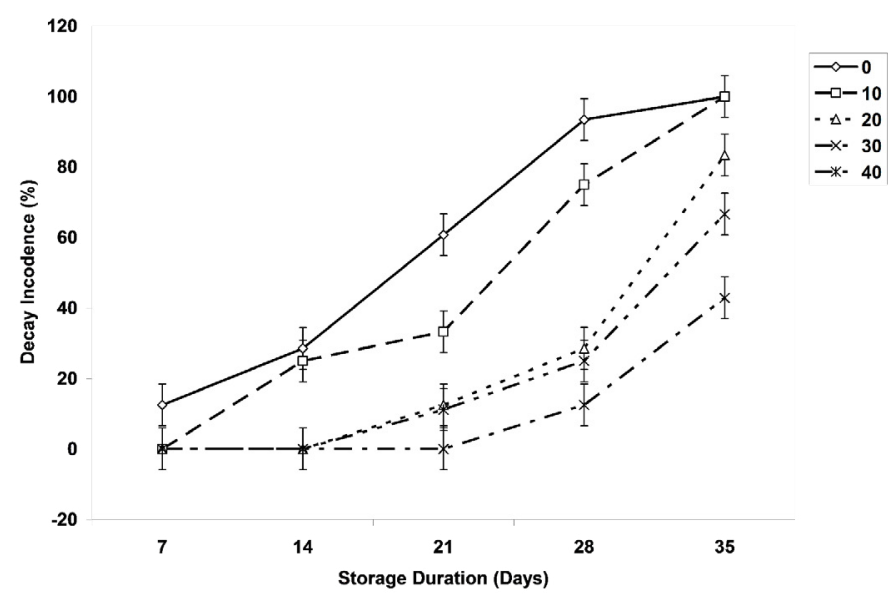

Figure 2: Decay incidence in persimmon fruits in relation to storage duration and Aloe vera gel concentrations. The error bars represent LSD at $P \geq 0.05$.
Organoleptic (Taste) score

The initial organoleptic quality score of control (0 days storage) fruit (4.52) increased with increasing the storage duration to the maximum of 7.95 after 21 days storage but then decline to 7.05 and 2.55 after 28 and 35 days storage respectively. Aloe vera gel application delayed the ripening and, hence, the maximum organoleptic quality score (8.92), after 35 days storage was for fruits treated with $10 \%$ Aloe vera gel followed by fruit taste score $8.77,7.75$ and 7.33 in fruits treated with 20, 30 and $40 \%$ of Aloe gel (Figure 3).

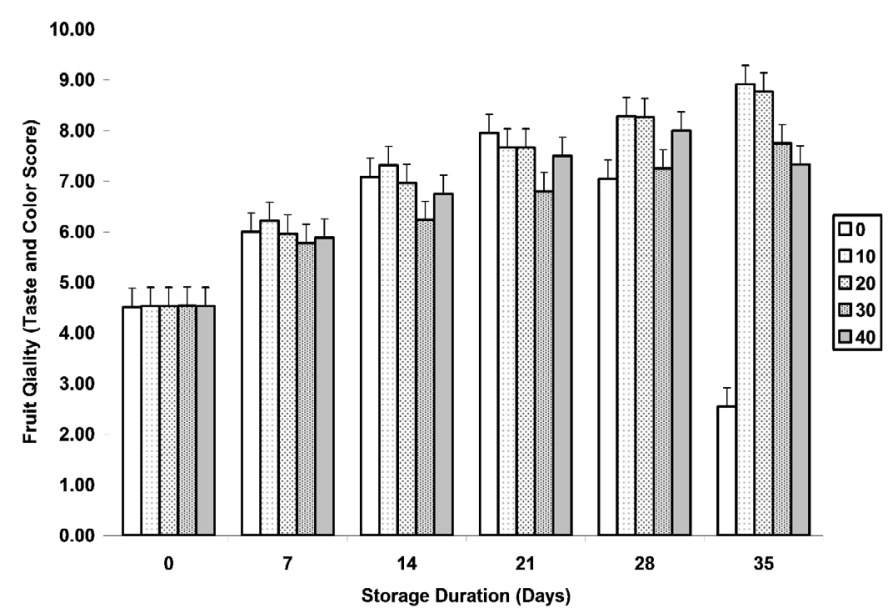

Figure 3: The influence of storage duration and Aloe vera gel concentrations on the organoleptic quality score of persimmon fruit. The vertical error bars represent $L S D$ at $P \geq 0.05$.

\section{Total soluble solids (Brix)}

The total soluble solids (TSS) of persimmon fruits was significantly $(\mathrm{P} \leq 0.05)$ affected by storage intervals, concentrations of Aloe vera gel and their interaction. The interaction of the Aloe vera gel concentration and storage durations indicates that the TSS content of persimmon fruit ranged from 12.4 to $13.2 \%$ in freshly harvested fruit (day 0 of storage) that increased significantly $(\mathrm{P} \leq 0.05)$ with increasing storage duration and was $37.56 \%$ after 35 days storage in control fruits ( $0 \%$ gel concentration). Application of Aloe vera gel retarded the increase in TSS so that it was significantly lower in gel treated fruits and was the minimum $(20.2 \%)$ in fruits treated with $30 \%$ Aloe vera gel after 35 days storage (Figure 4 ).

\section{Titratable acidity (\%)}

The storage durations, concentrations of Aloe vera gel and their interaction significantly $(\mathrm{P} \leq 0.05)$ affected the titratable acidity of persimmon fruits. Titratable acidity decreased with increased in storage intervals. The titratable acidity of the fruit was $0.29-0.30 \%$ on day 0 of storage that decreased to the minimum 0.06 
in control fruits after 35 days storage as compared to 0.09 and $0.11 \%$ in fruits treated with 10 and $20 \%$ Aloe vera gel respectively and stored for 35 days. The titratable acidity at the same storage duration (35 days) was the highest $(0.19 \%)$ in fruit treated with $30 \%$ Aloe vera gel followed by $0.14 \%$ in fruits treated with $40 \%$ Aloe vera gel application (Figure 5).

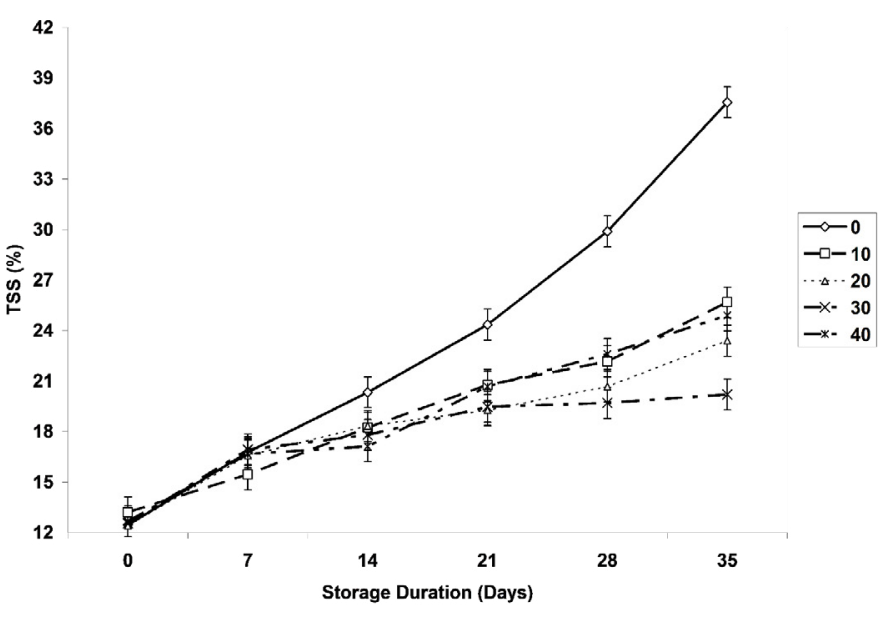

Figure 4: The influence of storage duration and Aloe vera gel concentrations on the total soluble solids (TSS) of persimmon fruit. The error bars represent LSD at $P \geq 0.05$.

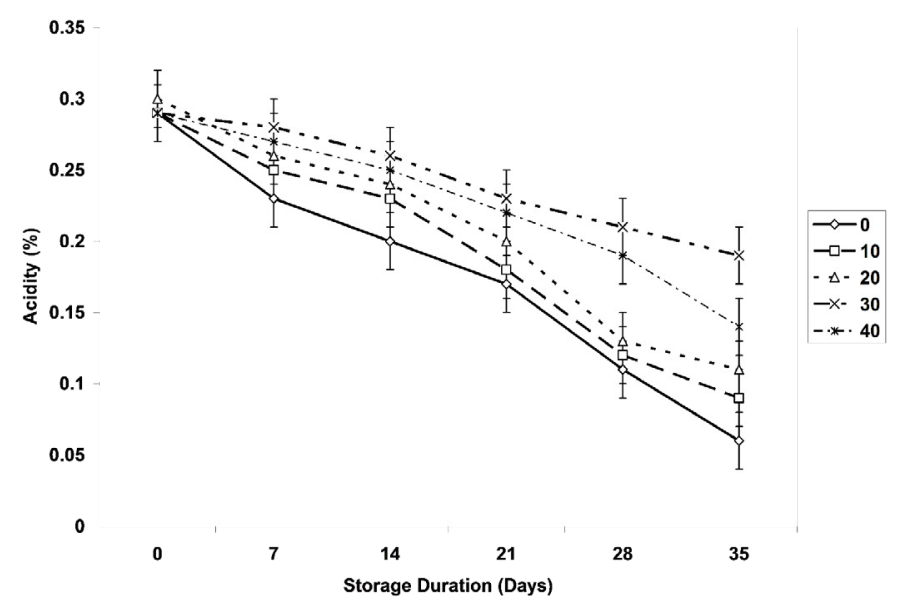

Figure 5: The influence of storage duration and Aloe vera gel concentrations on the percent acidity of persimmon fruit. The error bars represent $L S D$ at $P \geq 0.05$.

\section{Ascorbic acid ( $m g / 100 g$ )}

The ascorbic acid content of persimmon fruits decreased with increasing storage duration and its decline was significantly $(\mathrm{P} \leq 0.05)$ retarded by the application of Aloe vera gel. The ascorbic acid content of persimmon fruits was 46.33 to $46.70 \mathrm{mg} / 100 \mathrm{~g}$ in fresh fruits (day 0 of storage) that decreased significantly $(\mathrm{P} \leq 0.05)$ to $15.47 \mathrm{mg} / 100 \mathrm{~g}$ with 35 days storage in control fruit. By contrast, the ascorbic acid content of fruit treated with 10, 20, 30 and 40\% Aloe vera gel was $15.12,17.05,29.76$ and $18.31 \mathrm{mg} / 100 \mathrm{~g}$ accordingly (Figure 6).
60

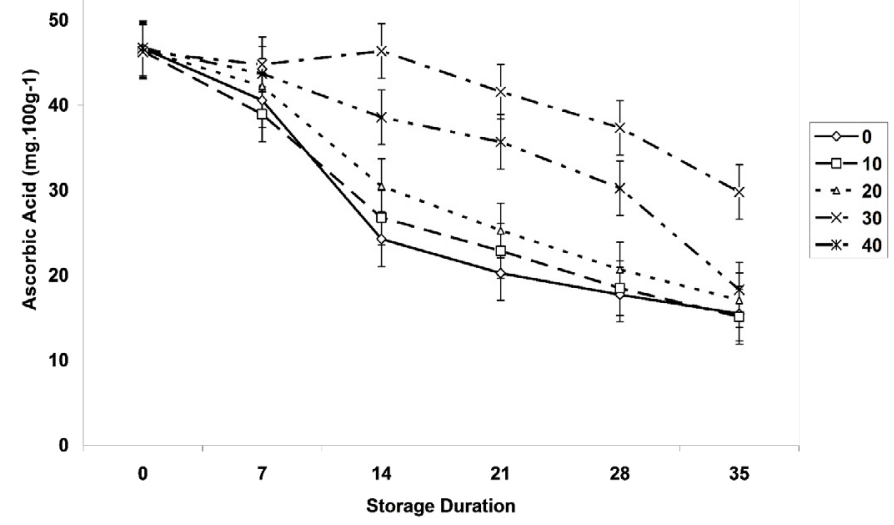

Figure 6: Changes in Ascorbic acid content of persimmon fruit in relation to storage duration and Aloe vera gel concentration. The error bars represent $L S D$ at $P \geq 0.05$.

The fruit firmness decreased with increasing storage duration but the decline was less than control with $30 \%$ with Aloe vera gel application (Figure 1). The loss of fruit firmness during storage of persimmon fruit is due to ripening and firmness of less than 10 $\mathrm{N}$ is regarded as undesirable (Salvador et al., 2004). The fruit firmness is due to cell wall strength (Vicente et al., 2007) and turgidity generated by the moisture content of the fruit (Simson and Straus, 2010). During fruit ripening, the insoluble protopectins are converted to soluble pectin and cross linked cell wall polysaccharides are degraded due to enhanced activities of polygalacturonase and pectin esterase that lead to decreased fruit firmness (Al-Juhaimi et al., 2012). Since, Aloe vera gel coating decrease the activities of polygalacturonase and pectineesterase enzymes (Vicente et al., 2007), therefore, retained the fruit firmness. The application of Aloe vera gel increases $\mathrm{CO}_{2}$ and decrease $\mathrm{O}_{2}$ inside the fruit (Salunkhe et al., 1991), which decreases the rate of respiration (Castillo et al., 2010) and ethylene production (Brishti et al., 2013) and, thus, delays ripening. Thus, the retention of fruit firmness by Aloe vera gel can also be due to modification of internal atmosphere of the fruit (Castillo et al., 2010).

The persimmon fruits are infected by variety of pathogens during storage (Khademi, 2012). Thus, the decay incidence increased with increasing storage duration due to ripening, which increases sensitivity to pathogen (Terry and Joyce, 2004). The application of Aloe vera gel delayed as well as decreased the decay incidence of persimmon fruit (Figure 2). However, fruit coating with $40 \%$ Aloe vera gel had higher decay incidence than $30 \%$ gel coating. This could 
be due to the complete filling up the fruit lenticel and terminating respiration by $40 \%$ of Aloe vera gel, however, $30 \%$ of Aloe vera gel only reduced the respiration rate and somehow fill up the fruit lenticel resulting in the extension of shelf life. Since, Aloe vera gel slow down the rate of ripening as well as the growth of microorganisms (Valverde et al., 2005; Mohebbi et al., 2011; Marpudi et al., 2013). Thus, Aloe vera gel application decrease disease incidence by making unfavorable environment for decay causing organism (Benitez et al., 2013).

The organoleptic quality of the fruit depends on color, taste and aroma (Aoun et al., 2013). Since the fruits continue the ripening process during storage and developed taste and color (Raza et al., 2013). The untreated persimmon (control) fruits ripened earlier during storage than the fruits treated with Aloe vera gel (Martinez-Romero et al., 2006). By contrast, the edible coating of Aloe vera gel reduces the rate of respiration and ethylene in diverse group of fruits (Chauhan et al., 2013; Guillen et al., 2013). Thus, it delayed the development of color and taste (Marpudi et al., 2013).

The total soluble solids (TSS) of persimmon fruits increased significantly with increasing storage duration but its increase was less in fruit treated with $30 \%$ Aloe vera gel (Figure 4). The total soluble solids content of the fruit contains about $75 \%$ sugars and its combinations with acidity determine the taste and flavor to the fruits. The total soluble solids content of the fruits, generally, increases during ripening and storage due to the increase in free sugars and decreased moisture content (Karki, 2005). Since, the polysaccharides contents of Aloe vera gel act as barrier against moisture loss from the fruits, thus, retard moisture loss (Misir et al., 2014) as well as delay the ripening (Ahmad et al., 2009; Brishti et al., 2013). Thus, it decreased the conversion of complex carbohydrates to free sugars (Crouch, 2003) and, thus, resulted in lower TSS in gel treated fruits.

The titratable acidity of the fruit decreased during 35 days storage but was retained at the highest value in fruit treated with 30\% Aloe vera gel (Figure 5). The titratable acidity of fruit is due to different organic acid present in the fruit (Simson and Straus, 2010). Since, these organic acids are used during respiration, the titratable acidity tend to decline during storage (Jan et al., 2015). The application of Aloe vera gel decreases the rate of respiration, thus, decrease the loss of organic acids and retain higher titratable acidity (Ahmad et al., 2009). Aloe vera gel acts as a barrier for the exchange of gases and increases the internal $\mathrm{CO}_{2}$ concentration and modify the internal atmospheric of the fruit that retard the ripening and decreases the decline of titratable acidity (Ergun and Satici, 2012).

The ascorbic acid content of persimmon fruits decreased significantly during storage in control fruit but was higher than control in fruits treated with Aloe vera gel (Figure 6). The ascorbic acid contents of the fruit decease with increasing storage duration (Jan et al., 2015) due to enhanced activity of ascorbic acid oxidase enzyme (Salunkhe et al., 1991). Aloe vera gel application on pineapple and oranges delayed the loss of ascorbic acid by decreasing the permeability of oxygen into the fruits (Misir et al., 2014) and so preventing the oxidation of ascorbic acid (Adetunji et al.,2012).It is however, interesting to observe that high gel concentration (40\%) caused significant reduction in ascorbic acid, probably by increasing internal $\mathrm{CO}_{2}$ levels that trigger ascorbic acid degradation (Lee and Kader, 2000).

\section{Conclusions and Recommendations}

It was concluded that persimmon fruit treated with $30 \%$ Aloe vera gel, as edible coating, ripened slowly during storage. Aloe vera gel application (30\%) retarded the increase in TSS and the loss of acidity and ascorbic acid as well as retained firmness. It also decreased the decay incidence and retained high organoleptic quality. However, lower (10 and 20\%) and high gel concentrations (40\%) were less effective in increasing the storage life and retaining quality of persimmon fruit.

\section{Acknowledgments}

This work is supported by Professor Dr. Abdur Rab, Chairman of the Department of Horticulture, Faculty of Crop Production Sciences, University of Agriculture, Peshawar 25130, Khyber Pakhtunkhwa, Pakistan during 2013-15.

\section{Novelty Statement}

The study is novel for fruit growers and preservwers 
as persimmon fruits treated with 30\% Aloe vera gel retains post-harvest quality of fruits. It also preserve it from deterioration for up to $\geq 35$ days of storage at room temperature.

\section{Author's Contribution}

The manuscript is based on the M.Sc (Hons) degree research work of Abdul Jalal under the supervision of Professor Dr. Abdur Rab, Abdul Jalal and Naveed Ahmad designed and performed the experiment. Abdur Rab analysed the results and edit the original draft of the manuscript.

\section{Conflicts of interest}

The authors declare no conflicts of interest.

\section{References}

Adetunji, C.O., A.B. Fawole, J.K. Oloke, J.B. Adetunji and O.R. Makanjoula. 2012. Effect of edible coatings from Aloe vera gel on Citrus sinensis during ambient storage. J. Agric. Res. Dev., 11(1): 77-84. https://doi.org/10.4314/ agrosh.v13i1.8

Ahmad, M.J., Z. Singh and A.S. Khan. 2009. Postharvest Aloe vera gel coating modulates fruit ripening and quality of 'Arctic Snow' nectarine kept in ambient and cold storage. Int. J. Food Sci. Technol., 44: 1024-1033. https:// doi.org/10.1111/j.1365-2621.2008.01873.x

Al-Juhaimi, A., K. Ghafoor and E.E. Babiker. 2012. Effect of gum arabic edible coating on weight loss, firmness and sensory characteristics of cucumber (Cucumis sativus L.) fruit during storage. Pak. J. Bot., 44: 1439-1444.

AOAC, 1990. Official method of analysis (15 $5^{\text {th }}$ ed.). Washington, DC: Association of official analytical chemists.

Aoun, A.B., B. Lechiheb, L. Benyahya and A. Ferchichi. 2013. Evaluation of fruit quality traits of traditional varieties of tomato (Solanum lycopersicum) grown in Tunisia. Afr. J. Food Sci., 7: 350-354. https://doi.org/10.5897/ AJFS2013.1067

Asghari, M., H. Khalili, Y. Rasmi and A. Mohammadzadeh. 2013. Influence of postharvest nitric oxide and Aloe vera gel application on sweet cheery quality indices and storage life. Int. J. Agron. Plant Prod., 4: 23932398.
Bagheri, M., M. Esna-Ashari and A. Ershadi. 2015. Effect of postharvest calcium chloride treatment on the storage life and quality of persimmon fruits (Diospyros kaki Thunb.) cv. 'Karaj'. Int. J. Hortic. Sci. Technol., 2: 15-26.

Baltacioglu, H. and N. Artik. 2013. Study of postharvest changes in the chemical composition of persimmon by HPLC. Turk. J. Agric., 37: 568-574. https://doi.org/10.3906/ tar-1210-21

Benitez, S., I. Achaerandio, F. Sepulcre and M. Pujola. 2013. Aloe vera based edible coatings improve the quality of minimally processed 'Hayward' kiwifruit. J. Postharvest Biol. Technol., 81: 29-36. https://doi.org/10.1016/j. postharvbio.2013.02.009

Brishti, F.H., J. Misira and A. Sarker. 2013. Effect of Bio preservatives on storage life of papaya (Carica papaya L.). Int. J. Food Stud., 2: 126136. https://doi.org/10.7455/ijfs/2.1.2013.a10

Castillo, S., D. Navarro, P.J. Zapata, F. Guillen, D. Valero, M. Serrano and D. MartinezRomero. 2010. Antifungal efficacy of Aloe vera in vitro and its use as a pre harvest treatment to maintain postharvest table grape quality. Postharvest Biol.Technol., 57: 183-188. https:// doi.org/10.1016/j.postharvbio.2010.04.006

Cha, D.S. and M.S. Chinnan, 2004. Biopolymerbased Antimicrobial Packaging. A review. Crit. Rev. Food Sci. Nutr., 44: 223-237. https://doi. org/10.1080/10408690490464276

Chauhan, O.P., C. Nanjappa, C. Ashok, N. Ravi, N. Roopa and N. Raju. 2013. Shellac and Aloe vera gel based surface coating for shelf life extension of tomatoes. J. Food Sci. Technol., 52: 12001205. https://doi.org/10.1007/s13197-0131035-6

Crouch, I., 2003. 1-Methylcyclopropene (Smart fresh TM) as an alternative to modified atmosphere and controlled atmosphere storage of apples and pears. Acta Hortic., 600: 433-436. https://doi.org/10.17660/ ActaHortic.2003.600.64

Del-Bubba, M., E. Giordani, L. Pippucci, A. Cincinelli, L. Checchini and P. Galvan, 2009. Changes in tannins, ascorbic acid and sugar contents in astringent persimmons during on tree growth and ripening and in response to different postharvest treatments. J. Food Compos. Anal., 22: 668-677. https://doi. org/10.1016/j.jfca.2009.02.015 
Ergun, M. and F. Satici. 2012. Use of Aloe vera gel as bio preservative for 'granny smith' and 'red chief' apples. J. Anim. Plant Sci., 22: 363-368.

Gorinstein, S., Z. Zachwieja, M. Folta, H. Barton, J. Piotrowicz, M. Zember, M. Weisz, S. Trakhtenberg and O. Martinbelloso. 2001. Comparative content of dietary fiber, total phenolics, and minerals in persimmons and apples. J. Agric. Food Chem., 49: 952-957. https://doi.org/10.1021/jf000947k

Guillen, F., H.M. Diazmula, P.J. Zapata, D. Valero, M. Serrano, S. Castillo and D. MatinezRomero. 2013. Aloe arborescens and Aloe vera gels as coatings in delaying postharvest ripening in peach and plum fruit. Postharvest Biol. Technol., 83: 54-57. https://doi.org/10.1016/j. postharvbio.2013.03.011

Jan, I., A. Rab and M. Sajid. 2015. Influence of calcium chloride on storability and quality of apple fruits. Pak. J. Agric. Sci., 52: 115-122.

Karki, D.B., 2005. Effect of harvesting states on the quality of tomato (Lycopersicon esculentum Mill) CV. Avinash-2 hybrid. Tribhuvan Univ. J. 105: 143-147.

Khademi, O., Z. Zamani, Y. Mostofi, S. Kalantari and A. Ahmadi. 2012. Extending storability of persimmon fruit cv. Karaj by postharvest application of salicylic acid. J. Agric. Sci. Tech., 14: 1067-1074.

Lee, S.K. and A.A. Kader. 2000. Preharvest and postharvest factors influencing vitamin $\mathrm{C}$ content of horticultural crops. Postharvest Biol. Technol.,20:207-220. https://doi.org/10.1016/ S0925-5214(00)00133-2

Mandal, S., N.Mallick and A. Mitra. 2009. Salicylic Acid-induced resistance to Fusarium oxysporum sp. lycopersici in Tomato. Plant Physiol. Bioch., 47: 642-649. https://doi.org/10.1016/j. plaphy.2009.03.001

Marpudi, S.K., P. Ramachandran and N. Srividya. 2013. Aloe vera gel coating for postharvest quality maintenance of fresh fig fruits. Res. J. Pharm. Biol. Chem. Sci., 4: 12-41.

Martinez-Romero, D.L., N. Alburquerque, J.M. Valverde, F. Guillen and S. Castillo, 2006. Post harvest cherry quality and safety maintenance by Aloe vera treatment: A new edible coating. Postharvest Biol. Technol., 39: 93-100. https:// doi.org/10.1016/j.postharvbio.2005.09.006

Misir, J., F.H. Brishti and M.M. Hoque. 2014. Aloe vera gel as a novel edible coating for fresh fruits.
Am. J. Food Sci. Technol., 2: 93-97. https://doi. org/10.12691/ajfst-2-3-3

Mohebbi, M., E. Ansarifar, N. Hasanpour, M. Reza and A. Yousefi. 2011. Suitability of Aloe vera and gum tragacanth as edible coatings for extending the shelf life of button mushroom. J. Food Bioprocess Tech. 5: 3193-3202. https:// doi.org/10.1007/s11947-011-0709-1

Ni, Y., D. Turner, K.M. Yates and I. Tizard. 2004. Isolation and characterization of structural components of Aloe vera leaf pulp. Int. Immunopharmacol. 4: 1745-1755. https://doi. org/10.1016/j.intimp.2004.07.006

Raza, S.A., A.S. Khan, A.U. Malik, M.A. Habat, U. Asad and K. Razzaq. 2013. Respiration rate, physico-chemical fruit quality and consumer acceptability for fajri mango under different storage temperatures. Pak. J. Agric. Sci., 50: 585-590.

Salunkhe, D.K., H.R. Boun and N.R. Reddy. 1991. Storage processing and nutritional quality of fruits and vegetables. Vol. $1 \mathrm{CRC}$ press Inc., Boston.

Salvador,A.,L.Arnal,A.Monterde andJ.Cuquerella. 2004. Reduction of chilling injury symptoms in Persimmon fruit cv. Rojo Brillante by 1-MCP. Postharvest Biol. Technol., 33: 285-291. https:// doi.org/10.1016/j.postharvbio.2004.03.005

Scalbert, A. and G. Williamson. 2000. Dietary intake and bioavailability of polyphenols. J. Nutr.,130:2073-2085.https://doi.org/10.1093/ $\mathrm{jn} / 130.8 .2073 \mathrm{~S}$

Serrano, M., J.M. Valverde and F. Guillen, S. Castillo, D. Martinez-Romero and D. Valero. 2006. Use of Aloe vera gel coating preserves the functional properties of table grapes. J. Agric. Food. Chem. 54: 3882-3886. https://doi. org/10.1021/jf060168p

Simson, A.P. and M.C. Straus. 2010. Post-harvest technology of horticultural crops Oxford Book Company 267, IO-B-Scheme, Opp. Narayan Niwas, Gopalpura, By Pass Road, Jaipur-302018. pp. 306.

Steel, R.G.D. and J.H. Torrie. 1997. Principles and procedures of statistics: A biometrical approach. $3^{\text {rd }}$ ed. McGraw-Hill, New York.

Suzuki, T., S. Someya and H.F.M. Tanokura. 2005. Comparative study of catechin compositions in five Japanese persimmons (Diospyros kaki). Food Chem., 93: 149-152. https://doi.org/10.1016/j. foodchem.2004.10.017 
Terry,L.A.and D.C.Joyce.2004.Elicitors of induced disease resistance in post harvest horticulture crops: A Brief Review. Postharvest Biol. Tecnol., 32: 1-13. https://doi.org/10.1016/j. postharvbio.2003.09.016

Valverde, J.M., D. Valero, D. Martinez-Romero, F. Guillen, S. Castillo and M. Serrano. 2005. Novel edible coating based on Aloe vera gel to maintain table grape quality and safety. J. Agric. Food Chem., 53: 7807-7813. https://doi. org/10.1021/jf050962v

Veberic, R., J. Jurhar, M.M. Petkovsek, F. Stampar and V. Schmitzer. 2010. Comparative study of primary and secondary metabolites in 11 cultivars of persimmon fruit (Diospyros kaki L.). Food Chem., 119: 477-483. https://doi. org/10.1016/j.foodchem.2009.06.044

Vicente, A.R., M. Saladie, J.K.C. Rose and J.M. Labavitch. 2007. The linkage between cell wall metabolism and fruit softening: looking to the future. J. Sci. Food Agric., 87: 1435-1448. https://doi.org/10.1002/jsfa.2837

Zheng, L.A., T. Nakatsuka, H. Matsumoto and G. Tamura. 2006. Pre-harvest nickel application to the calyx of 'Saijo' persimmon fruit prolongs postharvest shelf-life. J. Postharvest Biol. Technol.,24: 98-103.https://doi.org/10.1016/j. postharvbio.2006.05.001 